\title{
Utilising the International Human Rights Framework to Access the Benefits of Paediatric Research in The covid Era: A Wales Case Study
}

\author{
Rhian Croke \\ Children's Human Rights Adviser; PhD candidate, Hillary Rodham Clinton \\ School of Law, Human Rights Wales, Swansea, UK \\ rhiancrokehrw@gmail.com
}

\begin{abstract}
Rhian Thomas Turner
R\&D Lead, Noah's Ark Children's Hospital for Wales, PhD Candidate, Hillary Rodham Clinton School of Law, Swansea, UK rhian.thomas-turner@wales.nhs.uk
\end{abstract}

\author{
Phillip Connor \\ Consultant Paediatrician, R\&D Lead, Children and Women Clinical Board, \\ Cardiff and Vale UHB, Speciality Lead, Child Health, Health and Care \\ Research Wales, Cardiff, UK \\ philip.Connor@wales.nhs.uk
}

\author{
Martin Edwards \\ Consultant Paediatrician, Honorary Senior Lecturer, Cardiff University, \\ Cardiff, UK \\ martin.Edwards4@wales.nhs.uk
}

\begin{abstract}
This article uses Wales as a case study to discuss the challenges to accessing the benefits of paediatric research before and during the COVID-19 pandemic. Due to the rapidly changing political and legislative landscape, it is critical that health professionals working for the benefit of children can utilise international human rights treaties and the most relevant General Comments that offer a bridge between legalistic provisions and practice. Additionally, it is vital for health professionals to interpret and understand domestic children's rights legislation, including tools for implementation
\end{abstract}


for realising children's rights. This article shares learning from the Children's Hospital for Wales, Children and Young Adult Research Unit's endeavour to challenge the Welsh Government to pay due regard to the rights of the child in ensuring children can access the benefits of paediatric research; including research concerning children's role in infection and transmission, during the pandemic.

\section{Keywords}

Paediatric research - Convention on the Rights of the Child - International Covenant on Economic Social and Cultural Rights - Children's Rights Impact Assessments COVID-19 - School Closures - PIMS-TS - Wales

\section{1 \\ Introduction}

The Children and Young Adult Research Unit (CYARU) at the Children's Hospital for Wales reviewed the United Nations Convention on the Rights of the Child (CRC), and its General Comments, the International Covenant on Economic, Social and Cultural Rights (ICESCR) and its General Comments Nos. 14 and 25, to propose a children's rights perspective to children accessing the benefits of paediatric research. ${ }^{1}$ CYARU developed a children's rights perspective to paediatric research to provide a framework to advocate for children to access the benefits of quality paediatric research in Wales.

This article uses Wales as a case study to demonstrate the relevance and importance of the international human rights treaty obligations and domestic rights legislation to achieve change. The article first introduces the reasons why children are neglected in health research. Secondly, it considers the international human rights treaty obligations that should be included in a children's rights perspective to paediatric research. Thirdly, the article considers the challenges to implementing this in Wales, and how these entrenched challenges have continued during the covid era. It concludes that utilising the language of rights and international human rights treaty obligations can catalyse change for children. The reflections from this article will have relevance to other countries or regions trying to promote children's visibility in health research decision making and aid in challenging governments to prioritise children's rights in health care research environments.

1 For the purposes of this article, paediatric research refers to medical research with children o-17 years, conducted by professionals trained in paediatrics. 
Children are not "little adults" and have physiological and biological differences depending on their developmental stage ( $\mathrm{RCPCH}, 2012)$. However, the prevailing global research and development model is ill prepared to respond to the child population. As a result of a rapid period of growth and maturation that typifies childhood; children are split into smaller populations for drug development research (Joseph et al., 2015; European Commission, 2017). These small populations are insufficient stimuli for pharmaceutical companies to undertake paediatric research because of low return on investment (Joseph et al., 2015, European Commission, 2017). Lack of appropriate research for the paediatric population has resulted in medicines being used that are not appropriately tested. As a consequence, children are sometimes given ineffective medicines or medicines with unknown side effects (Joseph et al., 2015).

The UK ranks 19th in Europe for neonatal mortality and 2oth for under-5 mortality, dropping significantly from its position in 1990 (ONS, 2017). The UK Royal College of Paediatrics and Child Health $(\mathrm{RCPCH})$ state that children:

need biomedical and health services research that takes account of their changing physiology, and addresses their problems directly, generating evidence to improve the quality of the treatments and healthcare they receive, and the policies that affect their wellbeing ( $\mathrm{RCPCH}, 2012: 6)$.

However, according to the $\mathrm{RCPCH}$, funding for child health research (including paediatric research), has been decreasing year on year since 2012; academic paediatricians are still a small percentage of the UK paediatric workforce, have limited time for research in their work plans, and are not adequately represented on national research boards or committees (RСРCH, 2018). As reported by colleagues in Sweden, paediatric research, 'needs to be assessed, planned and coordinated by staff with the experience of paediatric research' (Kindblom et al., 2020). Although legislation was passed in Europe in 2007 to try and stimulate medicines development for children and whilst this legislation can claim some successes, there are still large unmet needs in paediatric treatments (European Commission, 2017).

Children, because of their minority status, also do not have the same opportunities as adults to assert their own interests, and demand accountability (Webb, 2011). Liebel argues that children experience discrimination, because they are 'prevented from having equal status, equal access to resources, equal access to decision-making, or to exercising rights in an equal manner', simply because they belong to a social group categorised as "children" (Leibel, 2014: 
120). Webb also refers to children's marginalisation when children are relegated to the status of non-persons and are not even seen as the part of core business or service (Webb, 2011).

It is also evident from the regulation of clinical research that children are conceptualised as distinctly vulnerable (Nuffield Council of Bioethics 2015a) and clinical research is often perceived to be first and foremost harmful to children (Bavdekar, 2013). The Nuffield Council of Bioethics argues that the assumption that all children are necessarily vulnerable may prevent valuable research from going ahead (Nuffield Council of Bioethics 2015a) and RCPCH comments that children require, 'considered protection, but this should not preclude the claim of other rights, including the right to the highest standard of health' (RCPCH, 2014: 2). All these factors contribute to a continued lack of prioritisation and investment in paediatric research.

Why is Access to Good Quality Paediatric Research a Children's Rights Issue?

International Covenant Economic Social and Cultural Rights, Right to Health and Right to Science

Article 12 of ICESCR states, the right to health includes, 'access to health facilities, goods, and services'. Although the ICESCR only requires the progressive realisation of the right to health in the context of limited resources, there is a core set of minimum obligations which are not subject to progressive realisation, including being able to 'access health services without discrimination' and 'equitable distribution of all health facilities, goods and services', including access to essential medicines (UNCESCR, 2000, para. 43). States are obliged under international human rights law to respect, protect and fulfil the right to health, which includes an obligation to adopt legislative, administrative and budgetary measures to facilitate access to services, including medicines, that are affordable, accessible, culturally acceptable and of good quality (UNCESCR, 2000). Each State must make every effort to use all available resources to meet these obligations (UNCESCR, 2000).

Article 15 (1) (b) of ICESCR, often considered to cover the 'right to science', provides an important backdrop on which to discuss paediatric research. The Article recognises the right of everyone to enjoy the benefits of scientific progress and its applications. Children are not covered in detail in the new General Comment No. 25 to this article; however, this obligation has significant relevance to children as a population group (UNCESCR, 2020). 


\subsection{Convention on the Rights of the Child}

The CRC provides two key articles directly related to the right to health: Article 6 concerning a child's inherent right to life and a States' obligation to ensure to the maximum extent possible the survival and development of the child, and Article 24 which recognises a child's right to the highest attainable standard of health. Fulfilling these obligations is often dependent on good quality paediatric research having been conducted (Joseph et al., 2015). Paediatric research, including clinical trials, is a major component in the development of evidence-based practice in the healthcare of children. Paediatric research supports access to 'appropriate prevention, health promotion, curative rehabilitative and palliative services' which are essential components if children are to realise their right to health (UN Committee on the Rights of the Child, 2013: 2).

The text of the CRC is however silent about research, including paediatric research, but given the interrelated and indivisible nature of the articles, many rights of the CRC are relevant to children achieving the benefits of research. The selected articles of the CRC and relevant CRC and ICESCR General Comments, considered relevant by CYARU to paediatric research, are outlined in Figure 1.

\subsection{AAAQ Framework}

The significance of the Availability, Accessibility, Acceptability and Quality (AAAQ) Framework is also of particular importance to paediatric research and is referenced in CRC General Comment No. 15 (UN Committee on the Rights of the Child, 2013), ICESCR General Comment No. 14 (UNCESCR, 2000) and ICESCR General Comment No. 25 (UNCESCR, 2020). These General Comments demonstrate that the right to health, access to medicines and benefits of scientific progress are dependent on these four interrelated elements. The AAAQ Framework in Figure 2 brings together the most pertinent elements of the three General Comments.

\subsection{Concluding Observations of the UN Committee on the Rights of the Child}

Additionally, CYARU utilised the most recent Concluding Observations of the UN Committee on the Rights of the Child 2016 to the UK State party (UN Committee on the Rights of the Child, 2016) as outlined in Figure 3.

CYARU has used this children's rights perspective to paediatric research to challenge Welsh Government (WG) to provide quality research for children, as well as using domestic rights legislation and is outlined in the next section. 


\begin{tabular}{|c|c|c|}
\hline $\begin{array}{l}\text { Article } \\
\text { of CRC }\end{array}$ & & General Comment \\
\hline 2 & $\begin{array}{l}\text { No child should be discriminated against on any } \\
\text { grounds and all children no matter their status or } \\
\text { background; should be able to access the benefits of } \\
\text { research. } \\
\text { Extra protection as well as equal opportunities, to } \\
\text { participate in research must be given to special groups } \\
\text { (See Articles } 20-23,25,32-36,38-40) \text {. }\end{array}$ & $\begin{array}{l}\text { CRC/GC3 (HIV/AIDS) } \\
\text { CRC/GC6 (Unaccompanied } \\
\text { children) } \\
\text { CRC/GC9 (Children with } \\
\text { Disabilities) } \\
\text { CRC/GC1o (Children in } \\
\text { juvenile justice system) } \\
\text { CRC/GC11 (Indigenous } \\
\text { children) } \\
\text { CRC/GC15 (Right to health) } \\
\text { CRC/GC18 (Gender } \\
\text { discrimination) } \\
\text { CRC/GC21 (Children on the } \\
\text { street) }\end{array}$ \\
\hline $3 \cdot 3$ & $\begin{array}{l}\text { In all actions concerning children, whether } \\
\text { undertaken by public or private institutions, the best } \\
\text { interests of the child shall be a primary consideration. } \\
\text { Institutions, services and facilities responsible for the } \\
\text { care or protection of children shall conform with the } \\
\text { standards established by competent authorities. }\end{array}$ & CRC/GC14 (Best Interests) \\
\hline 4 & $\begin{array}{l}\text { All economic, social and cultural rights, including the } \\
\text { right to attain the highest attainable standard of } \\
\text { health and access to medicines, must be implemented } \\
\text { to the maximum extent of available resources. }\end{array}$ & $\begin{array}{l}\text { CRC/GC5 (General Measures) } \\
\text { CRC/GC19 (Public budgeting) }\end{array}$ \\
\hline 5 & $\begin{array}{l}\text { Legal guardians must provide, in a manner consistent } \\
\text { with the evolving capacities of the child, appropriate } \\
\text { direction and guidance in the exercise by the child of } \\
\text { the rights recognised in the Convention. }\end{array}$ & $\begin{array}{l}\text { CRC/GC4 (Adolescent health) } \\
\text { CRC/GC7 (Early childhood) } \\
\text { CRC/GC15 (Right to health) } \\
\text { CRC/GC2o (Adolescence) }\end{array}$ \\
\hline
\end{tabular}

FIGURE 1 CYARU's summary description and interpretation of relevance to paediatric research 


\begin{tabular}{|c|c|c|}
\hline $\begin{array}{l}6.1 \\
6.2\end{array}$ & $\begin{array}{l}\text { Every child has the inherent right to life. } \\
\text { States Parties shall ensure to the maximum extent } \\
\text { possible the survival and development of the child. }\end{array}$ & $\begin{array}{l}\text { CRC/GC15 (Right to health) } \\
\text { ICESCR/GC } 14 \text { (Right to health } \\
\text { ICESCR } 15 \text { (1)(b) / GC } 25 \text { (Right } \\
\text { to science }\end{array}$ \\
\hline 12 & $\begin{array}{l}\text { The views of the child must be given due weight in } \\
\text { accordance with the age and maturity of the child; in } \\
\text { all aspects of the research process. }\end{array}$ & $\begin{array}{l}\text { CRC/GC12 (Right to be heard) } \\
\text { CRC/GC } 15 \text { (Right to health) }\end{array}$ \\
\hline 13 & $\begin{array}{l}\text { Children must have the right to freedom of expression, } \\
\text { including the right to seek, receive and impart } \\
\text { information; both are an important aspect of the } \\
\text { research process. }\end{array}$ & $\begin{array}{l}\text { CRC/GC } 12 \text { (Right to be heard) } \\
\text { CRC/GC15 (Right to health) }\end{array}$ \\
\hline 14 & $\begin{array}{l}\text { A child's right to freedom of thought, conscience and } \\
\text { religion; should be respected when conducting } \\
\text { research. }\end{array}$ & CRC/GC2o (Adolescence) \\
\hline 16 & $\begin{array}{l}\text { Children's right to privacy and unlawful attacks on the } \\
\text { child's honour and reputation; must be respected } \\
\text { throughout the research process. }\end{array}$ & CRC/GC 15 (Right to health) \\
\hline 17 & $\begin{array}{l}\text { Children should be able to access reliable information; } \\
\text { before, during and after the research process and } \\
\text { receive the published and disseminated findings. }\end{array}$ & CRC/GC15 (Right to health) \\
\hline 19 & $\begin{array}{l}\text { All children should be protected from abuse and } \\
\text { neglect; throughout the research process. }\end{array}$ & $\begin{array}{l}\text { CRC/GC8 (Corporal } \\
\text { punishment) } \\
\text { CRC/GC13 (Freedom from all } \\
\text { forms of violence) }\end{array}$ \\
\hline 24 & $\begin{array}{l}\text { States Parties must recognize the right of the child to } \\
\text { the enjoyment of the highest attainable standard of } \\
\text { health and to facilities for the treatment of illness and } \\
\text { rehabilitation of health. States Parties shall strive to } \\
\text { ensure that no child is deprived of his or her right of } \\
\text { access to such health care services. }\end{array}$ & CRC/GC15 (Right to Health) \\
\hline
\end{tabular}

FIGURE 1 Continued. 


\begin{tabular}{|c|c|c|}
\hline 27 & $\begin{array}{l}\text { Every child should have a standard of living adequate } \\
\text { for the child's physical, mental, spiritual, moral and } \\
\text { social development; without this fundamental right, } \\
\text { children will find it impossible to participate in or } \\
\text { enjoy the benefits of scientific progress. }\end{array}$ & ICESCR $15 /$ GC $_{25}$ \\
\hline 28 & $\begin{array}{l}\text { Every child has the right to an education; including as } \\
\text { an inpatient, research opportunities must be } \\
\text { developed that avoid missing education. }\end{array}$ & $\begin{array}{l}\text { CRC/GC1 (Aims of education) } \\
\text { CRC/GC15 (Right to health) }\end{array}$ \\
\hline 30 & $\begin{array}{l}\text { The child's ethnic and cultural identity; should be } \\
\text { respected throughout the research process. }\end{array}$ & CRC/GC15 (Right to health) \\
\hline 31 & $\begin{array}{l}\text { Every child has the right to rest, relax and play; when } \\
\text { engaging with research. }\end{array}$ & $\begin{array}{l}\text { CRC/GC15 (Right to health) } \\
\text { CRC/GC17 (Rest, play and } \\
\text { leisure) }\end{array}$ \\
\hline 36 & $\begin{array}{l}\text { Children must be protected against all forms of } \\
\text { exploitation prejudicial to any aspects of the child's } \\
\text { welfare. The balance of the benefits and the risks of } \\
\text { any research must be considered, and no child should } \\
\text { be exploited in any research process. }\end{array}$ & $\begin{array}{l}\text { CRC/GCi3 (Freedom from all } \\
\text { forms of violence) }\end{array}$ \\
\hline 37 & $\begin{array}{l}\text { No child should be subjected to torture or other cruel } \\
\text { or inhuman or degrading treatment; while } \\
\text { participating in any research. }\end{array}$ & $\begin{array}{l}\text { CRC/GCi3 (Freedom from all } \\
\text { forms of violence) }\end{array}$ \\
\hline
\end{tabular}

FIGURE 1 Continued.

Wales is one of the devolved regions of the United Kingdom, with a population of approximately 3 million people, of whom approximately 700,000 are children (o-17 years) (oNs, 2011). The National Assembly, established in 1999, secured executive powers to develop policy in the field of children's health, social care, education, transport, housing, play and leisure. Since 2006, there has been a Welsh Government (WG) and a separate parliament (today referred to as Senedd). Wales remains formally part of a single legal jurisdiction known as "England and Wales". The National Health Service Wales (NHS) is free at the point of use and is led by the WG Minister for Health and Social Services. 


\begin{tabular}{|c|c|}
\hline Availability & $\begin{array}{l}\text { States need to ensure that they have sufficient goods and services to support } \\
\text { children's right to survive and develop and right to health. Sufficiency should be } \\
\text { measured according to need with particular attention given to under-served } \\
\text { and hard to reach populations. This also relates to how goods, including } \\
\text { medicines, are produced and made available to the child population. States } \\
\text { parties should direct their own resources and coordinate actions of others to } \\
\text { ensure that scientific progress happens and that its applications and benefits } \\
\text { are distributed and are available, especially to vulnerable and marginalised } \\
\text { groups. This requires a strong research infrastructure with adequate resources. }\end{array}$ \\
\hline Accessibility & $\begin{array}{l}\text { Refers to children being able to access goods and services without } \\
\text { discrimination. Lack of ability to pay for healthcare should not result in the } \\
\text { denial of access. Information should be provided to children and their } \\
\text { caregivers in a language and format that is accessible and clearly } \\
\text { understandable to them. Everyone should have the open opportunity to } \\
\text { participate in scientific progress, without discrimination. }\end{array}$ \\
\hline Acceptability & $\begin{array}{l}\text { The development of goods and service must take account of and be respectful } \\
\text { of medical ethics, as well as children's needs, expectations, cultures, views and } \\
\text { languages, paying special attention to certain groups, where necessary. } \\
\text { Acceptability implies that scientific research has to incorporate ethical } \\
\text { standards in order to ensure its integrity and the respect of human dignity, such } \\
\text { as the standards proposed in the Universal Declaration on Bioethics and } \\
\text { Human Rights. Some of these standards are that the benefits to research } \\
\text { participants and other affected individuals should be maximised and any } \\
\text { possible harm minimised with reasonable protection and safeguards; the } \\
\text { autonomy and free and informed consent of participants should be guaranteed; } \\
\text { privacy and confidentiality should be respected; vulnerable groups or persons } \\
\text { should be especially protected in order to avoid any discrimination; and } \\
\text { cultural diversity and pluralism should be given due regard. }\end{array}$ \\
\hline Quality & $\begin{array}{l}\text { Ensuring quality requires, inter alia, that (a) treatments, interventions and } \\
\text { medicines are based on the best available evidence; (b) medical personnel are } \\
\text { skilled and provided with adequate training on maternal and children's health, } \\
\text { and the principles and provisions of the Convention; (c) all medicines are } \\
\text { scientifically approved and have not expired, are child-specific (when } \\
\text { necessary) and are monitored for adverse reaction; and (e) regular quality } \\
\text { assessment of institutions are conducted. }\end{array}$ \\
\hline
\end{tabular}

FIGURE 2 CYARU's summary description of and interpretation of relevance to paediatric research (AAAQ Framework, CRC/GC15, ICESCR/GC14 and GC25) 


\begin{tabular}{|c|c|}
\hline $\begin{array}{l}\text { Children's Rights Impact } \\
\text { Assessments } \\
\text { Para. } 10 \mathrm{~b}\end{array}$ & $\begin{array}{l}\text { Publish the results of such assessments and } \\
\text { demonstrate how they have been taken into } \\
\text { consideration in the proposed laws and policies. }\end{array}$ \\
\hline $\begin{array}{l}\text { Allocation of Resources } \\
\text { paras. } 12 \mathrm{~d}, \mathrm{e}\end{array}$ & $\begin{array}{l}\text { Regularly conduct child rights impact assessments of budget } \\
\text { and economic decision-making processes and outcomes. } \\
\text { Mechanisms must be established to monitor and evaluate the } \\
\text { adequacy, efficacy and equitability of the distribution of } \\
\text { resources allocated to the implementation of the Convention. }\end{array}$ \\
\hline $\begin{array}{l}\text { Respect for the Views of the } \\
\text { Child, para. } 31 \mathrm{a}\end{array}$ & $\begin{array}{l}\text { Establish structures for the active and meaningful participation } \\
\text { of children and give due weight to their views in designing laws, } \\
\text { policies, programmes and services at the local and national } \\
\text { levels. }\end{array}$ \\
\hline $\begin{array}{l}\text { Health and Health Services } \\
\text { para. } 59 \mathrm{a}, \mathrm{b}\end{array}$ & $\begin{array}{l}\text { Develop comprehensive and multi-sectoral strategies on child } \\
\text { health: with the allocation to the maximum extent of available } \\
\text { resources and a robust monitoring mechanism; with a strong } \\
\text { focus on eliminating inequalities in health outcome and in } \\
\text { access to health services. }\end{array}$ \\
\hline
\end{tabular}

FIGURE 3 Summary Description of UN Committee on the Rights of the Child's Concluding Observations to UK State party relevant to paediatric research

Devolution has accelerated significant progress on policy and legislation relating to children's rights in the Welsh context (Williams, 2013, Croke et al. 2021). Within the limits of the devolved settlement, the CRC has been incorporated into domestic legislation via the Rights of Children and Young Person's (Wales) Measure 2011 (Rights Measure, 2011). Although not direct incorporation, it does make it explicit that WG Ministers must have due regard to the rights of the child in all functions (Williams, 2013). The duty of due regard does not extend to other public bodies in Wales. Welsh Ministers, when exercising their duty of due regard, must also give consideration to the UN Committee on the Rights of the Child's General Comments and Concluding Observations (Rights Measure, Sec 3b. 2011). The Rights Measure requires Welsh Ministers to report on a scheme which sets out how they are delivering on their duty of due regard (Welsh Government, 2014). Children's Rights Impact Assessments (CRIAS) are included within the statutory scheme as a means for delivering on the duty (Welsh Government, 2014). CRIAs are a tool for proofing policy and legislation for compliance with the CRC, as recommended by the UN 
Committee on the Rights of the Child (UN Committee on the Rights of the Child, 2013).

Turning to paediatric research, the overall lack of visibility and neglect of children in health research outlined in Section 2 is experienced in the Welsh context, where paediatric research is under represented and under resourced. A new Welsh research infrastructure in 2015 resulted in a loss of focus on paediatric research and when the infrastructure was renewed in 2020, the issue was not resolved. Although a Speciality Lead for Child Health was created in 2017 with the remit of supporting paediatric research in the Welsh NHS, this post was only funded for 3.75 hours a week to increase paediatric research across Wales. Additional principal investigators and research delivery staff are required to drive the delivery of paediatric research.

These problems are compounded by WG funding models for reimbursement of clinical research. Wales has an Activity Based Funding (ABF) model which pays the NHS for each patient recruited into a WG approved study. This model does not work for low recruiting, highly complex studies that are prevalent in paediatric research. Paediatric research is more time intensive than most adult studies, additional time is required to obtain informed consent, ${ }^{2}$ in preparation of blood sampling in children, and involvement of specialist play teams to employ distraction techniques; all having a direct impact over the budget (Cardiff and Vale UHB, 2017). Although the ABF model may not be prima facie discriminatory against children, when practically applied there is a discriminatory impact.

Liebel argues that children experience indirect discrimination, 'because certain laws, regulations, measures, social norms, etc. that appear to be neutral and applicable to all persons equally are in fact detrimental to children as a social group' (Leibel 2014: 120). The ABF model, because its application leads to less funding to pay for necessary staff, results in children receiving fewer opportunities as compared to adults to participate in clinical studies. This means fewer opportunities to prolong life and to develop critical and age appropriate medicines. This discriminates against children, breaching Article 2 of the CRC and does not meet the requirements of the AAAQ framework which states that 'children must be able to access goods and services without discrimination' and 'that they have sufficient goods and services to support children's right to survive and develop and right to health' and they 'respect

2 With regards to participation in Clinical Trials in the UK, over 16-year olds can give consent, but under-16-year olds cannot (Clinical Trial of an Investigational Medicinal Product [Regulations]). CYARU ensures respect for the child's views and refusal to consent to participate, no matter the age of the child 
children's needs' (See Figure 2). It is not in accordance with what is in a child's best interests (Article $3 \mathrm{CRC}$ ), the child's right to survive and develop to their fullest potential (Article $6 \mathrm{CRC}$ ) and to achieve the highest attainable standard of health (Article $24 \mathrm{CRC}$ ) (Figure 1).

Paediatric cancer is an example of the real-life impact of the ABF model. Cancer is the leading cause of mortality in children aged o-9 years in Wales (RCPCH, 2020). Children with cancer, who have exhausted all their traditional treatment options, can be offered the opportunity to participate in early phase clinical trials, which may help to prolong their lives. However, there is no statutory funding for children to participate in these clinical trials in Wales. Children must leave the country to participate, meaning that children, in the most vulnerable and final stages of their lives, are leaving their home, siblings and extended family for the opportunity to take part (Cardiff and Vale UHB, 2017). This has also been demonstrated to have a significant impact on home finances, whereby parents may have to pay for accommodation and take time away from employment, whilst their child participates in a clinical trial in a hospital far from home (Cardiff and Vale UнB 2018). This affects the fulfilment of a child's right to an adequate standard of living guaranteed by Article 27 of the CRC (Figure 1). Children also struggle to continue with their education, affecting the fulfilment of the right to an education as laid out in Article 28 of the CRC (Figure 1). In contrast, adults can access early phase studies at three sites in Wales, further evidencing health inequity and discrimination towards children as a population group. CYARU repeatedly requested a CRIA on the review of the WG ABF funding model (Figure 3. Concluding Observation Paras $12 \mathrm{~d}, \mathrm{e})$.

Children who are affected by health budgetary decisions should be given accessible and child friendly information (Figure 1: Article 13, 17 of the CRC, CRC/GC 19, para $8 \mathrm{k}$ ) and consulted on these decisions (Figure 1: Article 12 of the CRC, CRC/GC 19, para 16). Children should also be given access to information and their views considered in the design, delivery and evaluation of paediatric research (Figure 1: Article 12 and CRC/GC 15 para 19, Figure 3: Concluding Observation $31 \mathrm{~b}$ ). For several years in England and Scotland, young people research advisory groups, have had government funding to contribute to the clinical research agenda (Generation R Alliance n.d; Scottish Children's Research Network n.d). The Nuffield Council on Bioethics has issued a statement of aspiration in relation to the importance of youth advisory groups influencing the design of paediatric research (Nuffield Council of Bioethics, 2015). In Wales, there are no mechanisms allowing children's views to be heard in the funding or delivery of paediatric research, suggesting disparity in funding across the UK State party. Although the funding of clinical research is a 
devolved health policy area, Williams argues 'deficiencies experienced by one young person, and not the other flowing from different policy choices, or structural arrangements [in Wales and England], could be characterised as unequal access to CRC rights within the State party' (Williams, 2011: 16).

Understanding why certain governmental budgetary decisions are made is often difficult to discern. In accordance with the UN Committee on the Rights of the Child, Governments are required to demonstrate transparency and whether budgetary decisions are in compliance with the CRC (UN Committee on the Rights of the Child, 2003: 2016). Under Article 4 of the CRC, Governments have a clear obligation to demonstrate whether they are fulfilling a child's right to health to the maximum extent of available resources. Transparent evidence on spending on children in relation to health research is an essential tool in meeting this obligation including evidence of whether planned spending and/ or spending cuts are impacting the best interests or the health outcomes of children (UN Committee on the Rights of the Child, 2016). CYARU requested that WG provide transparency in relation to investment they made into paediatric research and whether due regard to the rights of the child under the Rights Measure was considered in the allocation of the considerable amount of public funds under the wG Health and Care Research Wales Infrastructural 2020-2025 allocation. None of which was allocated to paediatric research. They were not forthcoming with this information.

\section{National Inquiry on Children's Rights in Wales}

With a duty to have due regard to the CRC placed upon WG Ministers, rather than a requirement to comply with the requirements of the CRC, enforcement can only be challenged through political and administrative scrutiny (Hoffman and Williams, 2013). Due to awaiting responses to the request for CRIAS, CYARU decided to utilise the option of political scrutiny. All concerns reported in Section 4 were shared via public written and oral evidence to the Senedd Children, Young People and Education Committee National Inquiry on Children's Rights in Wales (Senedd CYPE Committee) (Connor et al., 2019a).

The UN Committee on the Rights of the Child welcomes the emergence of parliamentary committees that give higher political priority to children and an increasing sensitivity to the impact of governance on children and their human rights' (UN Committee 2003: 9-10). In all evidence to the Senedd CYPE Committee, reference was made to the Rights Measure, and international human rights obligations and real-life examples were presented demonstrating children's inability to access the benefits of paediatric research. The health 
research case study demonstrated that WG was failing in their duty of due regard and the requirement of the Rights Measure's scheme to conduct CRIAS. The Chair of the Senedd CYPE Committee, referring to CYARU's oral evidence, commented:

It was a very powerful session that really did bring home to us the tangible and life changing difference putting children's rights at the heart of decision making can make to children and their families (CHAIR OF SENEDD CYPE COMMITTEE, 2O2O).

The Senedd CyPE Committee made 16 recommendations to WG. The WG accepted the majority of them, most notably that CRIAs must be published, the decision to not do CRIAs can be challenged, ministers and officials must receive training on the $\mathrm{CRC}$, and due regard must be considered in budgetary decisions (Welsh Government, 2020). The inquiry can be regarded as successful in further committing WG to deliver on their children's rights obligations.

The WG did however reject the recommendation to extend the duty of due regard to public bodies (Welsh Government, 2020). In advance of a parliamentary debate on the national inquiry on children's rights, CYARU, alongside the Children's Commissioner for Wales and Children in Wales, were invited to present further evidence. All parties argued that legislation should be tabled that combines the duty of due regard with a compliance model to create the opportunity for strengthening legal enforceability (Children's Commissioner for Wales 2020, Children in Wales 2020, Connor et al. 2020c; Senedd CYPE Committee, 2020b). This would mean that all public bodies in Wales (including WG) would have to comply with the CRC and children would have the right to seek remedy for a rights violation in a court of law. This is direct incorporation of the CRC (similar to the duty to act compatibly with the ECHR in the UK Human Rights Act $1998^{3}$ ). Kilkelly comments that 'indirect incorporation falls short of giving substantive protection to children's rights at a constitutional level' (Kilkelly, 2019: 7). However, she argues that, 'relatively weak measures of implementation can help to build momentum in favour of stronger measures' as observed in Scotland and Sweden who have moved towards more direct incorporation of the CRC (Kilkelly, 2019: 327). Positively, the wG reported in the parliamentary debate in January 2021 that they are in the process of strengthening equality and human rights legislation in Wales (Senedd, 2021).

3 Secyion 3 (1) of the Human Rights Act 1998. 

Pandemic

Alongside the above developments, the CoviD-19 pandemic continued to highlight the lack of priority given by WG to paediatric research. In June 2020 , CYARU wrote to the CYPE Committee emphasising they were concerned that the disregard to assessing the impact on children's rights was continuing with CRIAs not being shared publicly in relation to emergency legislation concerning COVID-19 (Connor et al., 2O2Ob). The UN Committee on the Rights of the Child stated:

the COVID 19 pandemic may have a significant and adverse impact on the availability of financial resources, these difficulties should not be regarded as an impediment to the implementation of the Convention (OHCHR, 2020: 34).

The UN Committee on the Rights of the Child, however, acknowledged that in times of crisis, it is necessary to restrict human rights in order to protect public health; these 'must be imposed only when necessary, be proportionate and kept to an absolute minimum' (OHCHR, 2O2O: 34).

After schools had been closed for three months (March to end of June 2020), it became clear that although some children were being admitted to hospital with COVID-19 related illnesses (ECDC, 202Oa), in general they suffer less severe symptoms (Mantovani et al., 2020). What was also increasingly evident was the collateral damage imposed on children by COVID-19, in particular the mental health impacts, the impact on access to education, access to nutritious food and the increased risk of significant harm ( Commissioners, 2020). Nolan comments that it is important fully to understand the impact of school closures on a wide range of human rights and to include consideration of impacts on both children and their interconnected communities in any decision-making process (Nolan, 2020). Significant risk to the right to life due to COVID-19 potentially makes the decision to close schools, proportionate. However, CYARU questioned whether the balance of the competing rights is possible to assess without sufficient evidence.

\subsection{Inconclusive Evidence to Justify Schools Opening or Closing: A Need for Paediatric Research}

When the decision was made to open schools in Wales in June 2020, there was inconclusive evidence on the role that children and schools played in rates of infection and transmission of the virus. This was agreed by the Welsh 
Government Technical Advisory Group on Education (WGTAG 2020a; WGTAG 2020b). In July, CYARU designed a research study to examine children and schools' role in rates of infection, transmission and antibody prevalence of COVID-19. CYARU tried to secure funding from WG, who advised on applying for grant funding and approached a UK-based charity who advised that this research was the responsibility of Government (Connor et al., 2O2Od). CYARU continued to monitor the emerging international evidence.

\subsubsection{International Evidence}

A systematic review of the evidence concluded that children and adolescents had lower susceptibility to COVID-19 for being an infected contact compared with adults (Viner et al., 2020). However, this review was completed between May and July 2020 when the majority of children were not in school. It concurred with the WG TAG, that evidence that children and adolescents play a lesser role than adults in transmission of CoviD-19 was weak. The majority of countries closed schools early in the pandemic, leaving little opportunity to study how the virus spreads in schools and back into the community. The research that had been conducted focused either at household level or the research in schools had been conducted shortly after national lockdowns in several countries, when infection rates in the community were better under control (ECDC, 2O2Ob).

Lael et al. warned in August that because children are so often asymptomatic, they could be spreading the infection at school and bringing it home unknown, as is seen with other respiratory viral infections (Lael et al., 2020). As Lael et al. explained, we may have reached the incorrect conclusion that the vast majority of people infected were adults because studies had mainly screened symptomatic subjects (Lael et al., 2020). Their study revealed that children may be a potential source of contagion in spite of milder disease or lack of symptoms (Lael M et al., 2020). A report carried out by the US Centers for Disease Control and Prevention indicated that children, even asymptomatic cases, may play an important role in transmission (Szablewski et al., 2020 ). Boast et al. reported from serologic screening conducted globally that approximately 5 o per cent of children may be asymptomatic, with only 10-15 per cent exhibiting symptoms (Boast et al., 2020).

The Public Health England (PHE) research in school settings was carried out at the end of lockdown when infection rates were lower and children were expected to socially distance in small class bubbles. It reported that there were 121 cases that were linked to outbreaks - 30 in children and 91 in staff. More than one million children attended school during the June to July period of the study and no children were admitted to hospital and only one staff member 
(Ismail et al., 2020). The report said there was a strong correlation between levels of community infection and the number of outbreaks in education settings; however, it was inconclusive regarding the spread of the virus from children to adults (Ismail et al., 2020).

PHE informed CYARU in August that they had not been funded to continue their research when schools reopened in September, a time when mitigating circumstances were different (i.e. no social distancing in primary schools, large class sizes, higher community infection rates and winter pressures). An article in The Lancet reported: 'we urgently need large-scale research programmes to carefully monitor the impact of schools reopening as Public Health Skids study aims to do' (Edmunds, 2020: 797).

The European Centre for Disease Prevention and Control (ECDPC) also concluded that there was still not comprehensive evidence regarding infectiousness of asymptomatic children and that outbreaks in schools may be difficult to detect (ECDPC 2O2Ob). ECDPC recommended that more specialised studies be conducted with the focus on children to better understand infection and antibody dynamics (ECDPC, 2020b). They also stated there was conflicting published evidence on the impact of school closure/reopening on community transmission levels, which also necessitated further research (ECDPC, 202ob). This lack of an evidence base was confirmed by Boast et al., who stated, 'the role of children in passing the disease to others is unknown, in particular given the unknown number of asymptomatic cases' (Boast et al., 2020).

\subsubsection{Children and Young People Recognised as Contracting the Virus but Children's Role in Transmission still Inconclusive}

According to data from the UK Office for National Statistics (ONS), infection rates were highest in older children and young adults, while the rate of infection among younger children was no different to adults (ONS, 202O). This indicated that children of all ages could contract the virus and could possibly infect others. In November an evidence review was finally published by WG TAG referring to the ons evidence that children were picking up and transmitting CoviD-19 at far higher levels than they first envisaged, particularly those in the 11 to 17 age group (TAG 2020C). The REACT study also confirmed that rates in school students were consistently seen to reflect rates in the general population (Riley et al., 2020). The WG TAG review indicated that although children were far more likely to be asymptomatic and not become seriously unwell, they were more likely to be the first positive case to any household (TAG, 2020c). They reported that the mechanism for this remained unclear and recommended that there should be research of specific school age cohorts to address unanswered questions relating 
to the balance between infection control and effective education for children. The review also recommended considering the feasibility of mass asymptomatic screening programmes in education institutions (TAG, 2O2OC).

Due to rising infection rates, at the end of December schools were again closed in Wales, and simultaneously the ECDPC reported that there was a need for further research:

as the role of children in CoviD-19 transmission is yet be fully elucidated and there is a need to determine the extent to which children are a) susceptible to SARS-CoV-2 virus across different age groups, and b) capable of transmitting infection to others when asymptomatic or symptomatic (ECDC, 2O2OC: 16).

In February 2021, a study undertaken by REACT reported the highest prevalence of COVID-19 was in children aged $5^{-12}$ years (and young people aged 18-24 years) (Riley et al. 2021). A Teaching Union in Wales threatened WG with legal action to protect teachers' right to life under the HRA 1998, if it resumed face-to-face teaching (Wightwick, 2021). Edmunds, reinforcing evidence from a UK Scientific Advisory Group for Emergencies, commented that opening schools could risk a resurgence of the virus (Weaver, 2021). Woolhouse, on the other hand, reported to a UK Parliamentary Committee that schools should be opened to children under 16 years, arguing that schools were essentially safe, younger children were not significant transmitters of the virus and there had been little evidence of school coviD-19 outbreaks across Europe (UK Parliamentary Committee, 2021).

The continued inconclusive evidence did little to clarify the role of children and schools in transmitting the virus. However, what became increasingly evident, were the significant harms done to children due to school closures (Viner et al., 2021). Lewis et al. argued in the absence of conclusive evidence, 'the precautionary principle would be to keep schools open to prevent catastrophic harms to children' (Lewis et al., 2021).

\subsection{PIMS-TS, Long-CovID and Vaccines for Children: A Need for Paediatric Research}

In April 2020 the first cases of a novel condition, PIMS-TS, were seen in UK hospitals ( $\mathrm{RCPCH} 2 \mathrm{O} 20$ ). This condition, associated with COVID-19, causes multi organ inflammatory syndrome in children and is considered to be a result of the immune system's response to the virus. With a new condition such as this, research becomes an essential component of the treatment pathway in 
order to determine the best possible care. A Delphi process ${ }^{4}$ was conducted to inform a national consensus document for treatment of PIMS-Ts but 'all participants recognise that this process has relied on clinical opinion based on the little evidence available' (Harwood et al. 2020:137).

In the UK the evidence needed for the treatment of PIMS-TS is primarily being generated through the adaptive UK Recovery Trial (Recovery Trial 20202021). CYARU is part of this trial and has recruited eight children into the study from across South Wales; with small numbers each participant generates vital data in the race to find treatments. These children will need to be followed up to understand if children are sufferers of Long covid, although there is currently little research in this area for children (Simpson et al. 2021).

The next research question to be answered relates to vaccinations in the paediatric population. Gostin commented at the end of 2020: 'the biggest gap in our Covid-19 vaccine plans is children' (Gostin, 2020). Early in February 2020, Oxford/Astrazeneca launched the first UK paediatric COVID-19 vaccine trial enrolling healthy volunteers from the age of six. Many other trials will follow as evidenced in the agreement of numerous Paediatric Investigation Plans (EMA, 2O2O). It is standard practice for paediatric trials to take place once adult trials have determined the general safety of the product in humans. Paediatric trials are essential in ensuring the efficacy of the intervention in children.

\section{Conclusion: Catalysing Change for Children}

The paediatric research infrastructure in Wales has been under resourced and represented and this has had a negative and discriminatory impact on children enjoying the fulfilment of their rights. CYARU, using the tool of political scrutiny, advocated that WG adhere to their children's rights obligations and successfully demonstrated that WG was failing in their duty of due regard and the requirement of the Rights Measure's scheme to conduct CRIAs. This scrutiny has contributed successfully to strengthening governmental accountability to children and promoted further legal enforceability of the CRC.

Additionally, political scrutiny using the language of rights has helped to initiate discussions between CYARU and WG officials on the future of paediatric research in Wales in the context of the new, four nations approach to clinical research (UK Department of Health and Social Care 2021). Furthermore, CYARU, representing the RСРCH, has been invited to contribute to the new Wales COVID-19 Evidence Centre's research prioritisation process and will

4 A national consensus pathway for paediatric inflammatory multisystem syndrome temporarily associated with COVID-19 (PIMS-TS): results of a national Delphi process. 
highlight the importance of research with children. This case study demonstrates that health professionals utilising international human rights treaties and domestic children's rights legislation can catalyse change for children.

However, it is inadequate that 12 months into the pandemic, Wales is yet to conduct robust research into the mechanisms of child and school transmission, despite denying children the fulfilment of many of their rights due to the impact of school closures. It is evident that this is not just an issue for Wales; health professionals in the UK and across Europe have also reported that children have not been prioritised as part of the pandemic research response (ECDC, 202Oc; Lewis et al., 2021,). Failure to prioritise such studies early in the pandemic has contributed to significant and long-lasting negative impacts on the human rights of children and their interconnected communities. It has also reduced opportunities to learn how best to support future generations to respond to future pandemics. In any CoviD-19 Inquiries the reasons why children were not prioritised as part of the initial pandemic research response must be considered and whether proportionate decisions were made that affected the fulfilment of their human rights.

Finally, there is an urgent need for a CRC General Comment on a children's rights perspective to paediatric research. Government and non-government institutions, health professionals, pharmaceutical companies and children themselves, must come together to share urgent dialogue on investing, prioritising and ensuring children can access the benefits of paediatric research globally.

\section{References}

Bavdekar, S. B., "Pediatric clinical trials", Perspectives in Clinical Research, 2013 (4(1)), 89-99. Doi:10.4103/2229-3485.106403.

Boast, A., Munro, A., Goldstein, H.,An evidence summary of Paediatric coviD 19 literature", Don't forget the Bubbles, 2020. Doi.org/10.31440/DFTB.24063.

Cardiff and Vale University Health Board, CYARU Internal Planning Documents (Cardiff and Vale University Health Board, 2017).

Cardiff and Vale University Health Board, Paediatric Oncology Internal Planning Documents (Cardiff and Vale University Health Board, 2018).

Chair of the Senedd Children and Young People and Education Committee, Twitter, $11 / 082020$.

Children's Commissioner for Wales, Children's Rights Inquiry Response $5^{\text {th }}$ November 2020. Available at: https://business.senedd.wales/documents/s1og281/ Additional\%2oinformation\%2ofrom\%2oChildrens\%2oCommissioner\%2ofor\%2o Wales\%2oregarding\%2oWelsh\%2oGovernments\%2oresponse\%2o.pdf. Accessed on 2 March 2021. 
Children in Wales, Children's Rights Inquiry Response, 5 November 2020. Available at: https://business.senedd.wales/documents/s1og279/Additional\%2oinformation\% 2ofrom $\% 20$ Children $\% 2$ oin $\% 20$ Wales $\%$ 2oregarding $\% 2$ othe $\% 20$ Welsh $\% 20$ Governments\%2oresponse\%20to\%2othe\%2oCommi.pdf. Accessed on 2 March $202 \mathrm{O}$. Clinical Trial of an Investigational Medicinal Product (Regulations), Available at: https://www.hra.nhs.uk/planning-and-improving-research/policies-standardslegislation/research-involving-children/. Accessed on 24 February 2021.

Connor, P., Croke, R. and Thomas Turner, R., a., "Senedd Children and Young People Education Committee National Inquiry into Children's Rights, Evidence submissions from Children's Hospital for Wales Research Unit", 2019 -2020 Available at: https:// business.senedd.wales/documents/s10928o/Additional\%2oinformation\%2o from\%2oNoahs\%2oArk\%2. Accessed on 17 February 2021.

Connor, P., Croke, R., Thomas-Turner, R., b., "Evidence Submission to the Senedd Children and Young People and Education Committee Inquiry into Covid 19", 2 June 2020. Available at: https://business.senedd.wales/documents/s102766/ CYPE\%2OCOV\%2O96\%2O-\%2oNoahs\%2oArk\%2oChildrens\%2oHospital\%2O 2\%20June\%2oPublished\%2010\%2oSeptember.pdf. Accessed 20 Feburary 2021.

Connor, P., Croke, R., Edwards, M., Thomas-Turner, R., and Tuthill, D., c., "Submission to the Senedd Children and Young People Education Committee in advance of the Senedd's Plenary Debate on Children's Rights", 5 November 2020 . Available at:https:// business.senedd.wales/documents/s10928o/Additional\%2oinformation \%20 from\%2oNoahs\%20Ark\%2. Accessed 17 February 2021.

Connor, P., Croke., R, Thomas-Turner, R., Edwards, M., d., "Children and schools need proper research to understand their role in, infection and transmission of COVID-19, to safeguard the human rights of children and their school communities", Evidence Submission to Seneddd Children and Young People and Education Committee, 30 November 2020 Available at: https://business.senedd.wales/documents/s112782/ CYPE\%2oCOV\%2O96a\%2O-\%2oNoahs\%2oArk\%2oChildrens\%2oHospital\%2O for $\% 20$ Wales $\% 2030 \% 2$ ONovember\%2O2O2०\%2oPublished\%2Oon\%2O15\%2O February\%20.pdf. Accessed March 302021.

Croke, R., Dale, H., Dunhill, A., Roberts, A., Unnithan, M., Williams, J., "Integrating Sustainable Development and Children's Rights: A Case Study on Wales", Soc. Sci. 2021, 10, 100. Doi.org/10.339o/socsci10030100.

Davies, P., Evans C., Kanthimathinathan H. K., Lillie J., Brierley J., Waters G., Johnson M., Griffiths B., du Pré P., Mohammad Z., Deep A., Playfor S., Singh D., Inwald D., Jardine M., Ross O., Shetty N., Worrall M, Sinha R., Koul A., Whittaker E., Vyas H., Scholefield B. R., Ramnarayan P., "Intensive care admissions of children with paediatric inflammatory multisystem syndrome temporally associated with SARS-CoV-2 (PIMS-TS) in the UK: a multicentre observational study", Lancet Child Adolesc Health 2O2O; 4: 669-77. 
Edmunds, W. J., "Finding a path to reopen schools during the COVID 19 pandemic", The Lancet, 2020 (4(11)), 796-797. Doi.org/10.1016/S2352-4642(20)30249-2.

EMEA-oo2893-PIPo1-20; EMEA oo2861-PIPo2-20; EMEA-oo2862-PIP-o1-2O.

European Centre for Disease Prevention and Control a., Rapid risk assessment: Paediatric inflammatory multisystem syndrome and SARS-CoV-2 infection in children (ECDPC, 15 May 2020) Available at: https://www.ecdc.europa.eu/en/publicationsdata/paediatric-inflammatory-multisystem-syndrome-and-sars-cov-2-rapid-riskassessment. Accessed 10 February 2021.

European Centre for Disease Prevention and Control b., covID 19 and the role of school settings in COVID 19 transmission (ECDPC, 6 August 2020). Available at: https://www. ecdc.europa.eu/sites/default/files/documents/coviD-19-schools-transmissionAugust\%2O2O2O.pdf. Accessed 15 August 2020.

European Centre for DiseasePrevention and Controlc., COVID-rginchildrenand theroleof schoolsettings in transmission - first update (ECDPC, 23 December 2020). Available at: https://www.ecdc.europa.eu/en/publications-data/children-and-school-settingsCOVID-19-transmission. Accessed 28 January 2021.

European Commission, State of Paediatric Medicines in the EU ro years of the EU Paediatric Regulation, сом (European Commission 2017). Available at: 2017_ childrensmedicines_report_en.pdf (europa.eu). Accessed 7 February 2021.

Generation $\mathrm{R}$ Alliance, Available at: https:/generationr.org.uk/about/\#: :text= GenerationR\%2ois\%20a\%2oNational\%2oNetwork\%20\%28GenerationR\%2O Alliance $\% 29 \% 2$ oof,and\%2odelivery\%2oof\%2opaediatric\%2oresearch\%2oin\%2O the\%2oUK. Accessed 20 March 2021.

Gostin L., Twitter 22/11/2020 @Lawrence Gostin.

Hoffman, S, and Williams, J., "Accountability", in , J. Williams (ed.), The United Nations Convention on the Rights of the Child in Wales (Cardiff: University of Wales Press, 2013).

ICH E11 (R1): https://www.ema.europa.eu/en/ich-e11r1-step-5-guideline-clinicalinvestigation-medicinal-products-pediatric-population. Accessed 20 February 2021. Ismail S. A., Saliba, V., Berna, J. L., Ramsay M. E., Ladhani S. N., "SARS-CoV-2 infection and transmission in educational settings: cross-sectional analysis of clusters and outbreaks in England", The Lancet 2020 (21(3)): https://assets.publishing.service. gov.uk/government/uploads/system/uploads/attachment_data/file/911267/ School_Outbreaks_Analysis.pdf. Accessed 6 February 2021.

Joseph, P. D., Craig, J. C., Caldwell, P. H., "Clinical trials in children", British Journal of Clinical Pharmacology 2015 (79(3)), 357-369. Doi:10.1111/bcp.12305.

Kilkelly, U.,"The UN convention on the rights of the child: incremental and transformative approaches to legal implementation", The International Journal of Human Rights, 2019 (23(3)), 323-337.

Kindblom J., Kjellen T., Finizia, C., Milsom, I., Mellgrem, K., "The Convention on the Rights of the Child (UNCRC) and its implementation in paediatric clinical research", ActaPaediatrica $2020(109(12))$. 
Lael, M., Yonker, Neilan, A. M, Bartsch, Y., Alter, G., PhD., Fasano, A., "Clinical Presentation, Infectivity, and Immune Responses", Journal of Paediatrics, 2020. Available at: https://www.jpeds.com/article/Soo22-3476(20)31023-4/abstract. Accessed 31 August 2020.

Lewis, S J., Munro, P S., Davey, Smith G., "Closing schools is not evidence based and harms children," BMJ 2021; 372: n521 23rd February 2021 http://dx.doi.org/10.1136/ bmj.n521 Accessed 19 March 2021.

Liebel, M., "Adultism and Age Based Discrimination against children", in , D. Kutsar and , H. Warming (eds.), Children and non-discrimination, inter-disciplinary textbook (University of Estonia Press, 2014), 1.

Mantovani, A., Rinaldi E., Zusi C., Beatrice G., Saccomani M. D., Dalbeni, A., "Coronavirus disease 2019 (COVID-19) in children and/or adolescents: a meta-analysis", Pediatric Research, 2020:1-6.

Nolan, A., "What human rights can tell us about school closures", Prospect Magazine 9 January 2021. Available at: https://www.prospectmagazine.co.uk/politics/schoolclosures-education-human-rights-law-COviD. Accessed 5 February 2021.

Nuffield Council on Bioethics, Summary of report, Children and clinical research: ethical issues (Nuffield Council of Bioethics, 2015 a).

Nuffield Council of Bioethics, Statement of aspiration: Improving research by involving children and young people (Nuffield Council of Bioethics, 2015 b).

Office for National Statistics, 2001 and 2011 Census: http//:www.statistics.gov.uk/. Accessed 19 December 2020.

Office of National Statistics Data Available online: https://www.ons.gov.uk/ peoplepopulationandcommunity/healthandsocialcare/childhealth. Accessed 19 December 2020.

OHCHR Human Rights Treaty Branch, Compilation of Statements by Human Rights Treaty Bodies in the context of COVID 19 (Geneva, September 2020). Available at: https://bangkok.ohchr.org/wp-content/uploads/2020/o5/External-TB-statementsCOVID-19-28apr201.pdf.

ons Infection Control Study. Available at: https://www.ons.gov.uk/people populationandcommunity/healthandsocialcare/conditionsanddiseases/bulletins/ coronavirusCOVID19infectionsurveypilot/6november2020\#age-analysis-of-thenumber-of-people-in-england-who-had-covid-19. Accessed 2o Feburary 2021.

Panovska-Griffiths, J., Kerr, C. C., Stuart, M. R., Mistry, D., Klein, D. J., Viner, N. R., Bonnell, C., "Determining the optimal strategy for reopening schools, the impact of test and trace interventions, and the risk of occurrence of a second wave of CoviD 19 epidemic", Lancet Child Adolescent Health 2020.

$\mathrm{RCPCH}$, Turning the Tide: harnessing the power of child health research ( $\mathrm{RCPCH} 2012)$. Available at: https://www.rcpch.ac.uk/sites/default/files/Turning_the_Tide_Full_ Report_2012.pd. Accessed 21 February 2021. 
RCPCH, Working party of the Royal College of Paediatrics, Guidance on clinical research involving infants, children and young people: an update for researchers and research ethics committee ( $\mathrm{RCPCH}, 2 \mathrm{O} 4)$.

RCPCH., Turning the Tide - Five years on ( rcpch.ac.uk/resources/turning-tide-five-years. Accessed 15 January 2021.

RCPCH, State of Child Health 2020: Wales (RCPCH, 2O2O).

RCPCH: https://www.rcpch.ac.uk/resources/pims-COVID-19-linked-syndrome-affectingchildren-information-families. Accessed 19 February 2021.

RСРС ., "Evidence submitted to the UK Parliamentary Select Committee for Children". Available at: https://committees.parliament.uk/writtenevidence/587o/pdf/. Accessed 24 February 2017.

Recovery Trial: https://www.recoverytrial.net/. Accessed 9 February 2021.

Rights of Children and Young Persons (Wales) Measure 2011, Available online: https:// www.legislation.gov.uk/mwa/2011/2. Accessed 27 February 2021.

Rights of Children and Young Persons (Wales) Measure 2011, Section $3 \mathrm{~b}$.

Riley, S., Walters, C., Wang, H., Eales, O., Ainslie, K., Atchison, C., Fronterre, C., Diggle, P. J., Ashby, D., Donnelly, C., Cooke, G., Barclay, W., Ward, H., Darzi, A., Elliott, P., REACT-1 round 7 updated report: regional heterogeneity in changes in prevalence of SARS-CoV-2 infection during the second national COVID-19 lockdown in England (Imperial College London, 15 November. Published December 2020).

Riley, S., Walters, C., Wang, H,. REACT-1 round 9 interim report: downward trend of SARS-CoV-2 in England in February 2021 but still at high prevalence. Available at: https://spiral.imperial.ac.uk/handle/10044/1/86126. Accessed 24 February 2021 (Imperial College London, February 2021).

Scottish Children's Research Network. Available at: https://www.scotcrn.org/. Accessed 20 March 2021.

Senedd Children and Young People and Education Committee a., National Inquiry Report into Children's Rights (Senedd Children and Young People Education Committee August 26 2020). Available at: https://senedd.wales/laid\%2odocuments/ cr-ld13405-r/cr-ld13405-r-e.pdf. Accessed 15 January 2021.

Senedd Children and Young People and Education Committee b., "Letter to the Deputy Minister Health and Social Services regarding the children's rights report: next steps", 4 December 2020. Available at: https://business.senedd.wales/documents/s1og886/ Letter\%2 ofrom $\% 2$ othe $\% 20$ Chair $\% 2$ oof\% $\%$ othe $\% 20$ Children $\% 2$ OYoung\%20 People\%2oand\%2oEducation\%2oCommittee\%2oto\%2othe\%2oDeputy\%20 Minister\%2o.pdf. Accessed 6 January 2021.

Senedd, Record of Proceedings (Senedd, 20 January 2021).

Simpson, F. K., Lokugamage A. U., "The elephant and the blind men: the children of long COVID", British Medical Journal 2021:372, n. 157. Doi:10.1136/bmj.n157 pmid:33468452. Szablewski, C. M., Chang K. T., Brown, M. M. et al., "sARs-CoV-2 Transmission and Infection Among Attendees of an Overnight Camp - Georgia June 2020", MMWR 
MorbMortalWkly Rep 2020; 69:1023-1025, Available at: https://www.cdc.gov/ mmwr/volumes/69/wr/mm6931e1.htm. Accessed 7 February 2021.

UK Children's Commissioner's Report, Children's rights in the UK in the context of the COVID-19 pandemic, Annex to Report of the UK Children's Commissioners to the United Nations Committee on the Rights of the Child: Examination of the Combined Sixth and Seventh Periodic Reports of the United Kingdom of Great Britain and Northern Ireland, December 2020. Available at: https://www.childrenscommissioner.gov. uk/wp-content/uploads/2020/12/cco-uncrc-report-COVID-annex.pdf. Accessed 2 January 2021.

UK Department of Health and Social Care, Saving and improving lives: the future of UK Clinical Research Delivery (UK Department of Health and Social Care 20201). Available at: https://assets.publishing.service.gov.uk/government/uploads/system/ uploads/attachment_data/file/971971/The-future-of-UK-clinical-research-deliveryfinal.pdf. Accessed 25 March 2021.

UK Human Rights Act 1998. Available at:https://www.legislation.gov.uk/ukpga/1998/42/ contents. Accessed 27 February 2021.

UK Parliamentary Committee,"Oral Evidence, Professor Woolhouse, University of Edinburgh", UK Parliamentary Committee, 16 February 2021. Available at: https://committees.parliament.uk/committee/135/science-and-technologycommittee-commons/news/139311/ea.

UN Committee on Economic, Social and Cultural Rights, General Comment No. 14 on the Right to the Highest Attainable Standard of Health, E/C.12/200o/4.

UN Committee on Economic, Social and Cultural Rights, General comment No. 25 on science and economic, social and cultural rights (article 15 (1) (b), (2), (3) and (4) of the International Covenant on Economic, Social and Cultural Rights), 2020.

UN Committee on the Rights of the Child, General Comment No. 1 on the aims of education, $\mathrm{CRC} / \mathrm{GC} / 2001 / 1$.

UN Committee on the Rights of the Child, General Comment No. 3 on HIV/AIDs and the rights of the child. $\mathrm{CRC} / \mathrm{GC} / 2003 / 3$.

UN Committee on the Rights of the Child, General Comment No. 4 Joint General Comment on the Protection of the Rights of All Migrant Workers and Members of their families on state obligations regarding the human rights of children in the context of internation migration in countries of origin. Transit, destination and return, 16 November 2017 .

UN Committee on the Rights of the Child, General Comment No.5. General Measures of Implementation, CRC/C/GC 5/2003.

UN Committee on the Rights of the Child, General Comment No. 6 on the treatment of unaccompanied and separated children outside of their country of origin, CRC/GC/2005/6

UN Committee on the Rights of the Child, General Comment No.7 on implementing child rights in early childhood CRC/C/GC/7 Rev.1/20o6. 
UN Committee on the Rights of the Child, General Comment No.8 on the right of the child to protection from corporal punishment and other cruel and degrading treatment, CRC/C/GC/8/2007.

UN Committee on the Rights of the Child, General Comment No. 9 on the rights of children with disabilities, CRC/C/GC/9/2006.

UN Committee on the Rights of the Child, General Comment No.1o on children's rights in juvenile justice, $\mathrm{CRC} / \mathrm{C} / \mathrm{GC} / 10 / 2007$.

UN Committee on the Rights of the Child, General Comment No. 12 on the right of the child to be heard, $\mathrm{CRC} / \mathrm{C} / \mathrm{GC} 12 / 2009$.

UN Committee on the Rights of the Child, General Comment No. 13 on the right of the child to freedom of all forms of violence, $\mathrm{CRC} / \mathrm{C} / \mathrm{GC1} 3 / 2011$.

UN Committee on the Rights of the Child, General Comment No. 14 on the right of the child to have his or her best interests taken as a primary consideration, CRC/C/GC/14/2013.

UN Committee on the Rights of the Child, General Comment No. 15 on the right of the child to the enjoyment of the highest attainable standard of health, CRC/C/15/2013. UN Committee on the Rights of the Child, General Comment No. 17 on the right of the child to res, leisure, play, recreational activities, cultural life and the arts, $\mathrm{CRC} / \mathrm{C} / \mathrm{GC} / 17 / 2013$.

UN Committee on the Rights of the Child, General Comment No. 18, Joint general recommendation No. 31 of the Committee on the Elimination of Disrimination against women/General Comment No. 18 of the Committee on the Rights of the Child on harmful practices, CEDAW/C/GC/31/CRC/C/GC18.

UN Committee on the Rights of the Child, General Comment No. 19 on public budgeting for the realization of children's rights, CRC/C/GC /19/2016.

UN Committee on the Rights of the Child, General Comment No. 20 on the implementation of the rights of the child during adolesence, $\mathrm{CRC} / \mathrm{C} / \mathrm{GC} / 20 / 2016$.

UN Committee on the Rights of the Child, General Comment No. 21 on children in street situations, $\mathrm{CRC} / \mathrm{C} / \mathrm{GC} / 21 / 2017$.

UN Committee on the Rights of the Child, Concluding observations on the fifth periodic report of the United Kingdom of Great Britain and Northern Ireland 2016, Available at: https://tbinternet.ohchr.org/_layouts/15/treatybodyexternal/ Download.aspx?symbolno=CRC/C/GBR/CO/5\&Lang=Enhttps://tbinternet.ohchr. org/_layouts/15/treatybodyexternal/Download.aspx?symbolno=CRC/C/GBR/ $\mathrm{CO} / 5 \&$ Lang=En. Accessed 20 January 2021.

Viner, R. M., Mytton, O. T., Bonell, C. et al., "Susceptibility to SARS-CoV-2 Infection Among Children and Adolescents Compared with Adults: A Systematic Review and Meta-analysis", JAMA Pediatr. Published online on 25 September 2020. Doi:10.1001/ jamapediatrics.2O2O.4573.

Waterfield. T., Watson C., Moore, R., Ferris, K., Tonry, C., Watt, A. P., McGinn., Foster, S., Evans, J., Lyttle, M. D., Ahmad S., Ladhani, S., Corr, M., McFetridge, L., Mitchell, 
H., Brown, J., Amirthalingam, G., Maney, J. A., Christie S., "Seroprevalence of SARS-CoV-2 antibodies in children: a prospective multicentre cohort study", Archives of Disease in Childhood. Published online first on 10 November 2020. Doi: 10.1136/archdischild-2020-320558.

Weaver, M., "Johnson pressed over plans to reopen schools in England on 8 March" (Guardian News Online, 21 February 2021).

Webb. E., "An exploration of the discrimination-rights dynamic", in , A. Invernizzi and J. Williams (eds.), The Human Rights of Children: From Visions to Implementation (Farnham: Ashgate, 2011).

Welsh Government., Children's Rights Scheme (Welsh Government 2014). Available at: https://senedd.wales/Laid\%2oDocuments/GEN-LD9732\%20-\%2oChildren's\%2o Rights\%2oScheme\%2O2O14-22042014-255569/gen-ld9732-e-English.pdf. Accessed 10 February 2021.

Welsh Government Technical Advisory Group Children and Education, a., Our latest understanding of COVID-19 with respect to children and education, 3 June 2020. Available at: https:/gov.wales/sites/default/files/publications/202O-o6/our-latestunderstanding-of-coviD-19-\%2ore. Accessed 10 February 2021.

Welsh Government Technical Advisory Group Children and Education, b., Our latest understanding of COVID-19 with respect to children and education, 7 July 2020. Available at: https://gov.wales/sites/default/files/publications/2020-07/technicaladvisory-group-advice-from-children-and-education-subgroup_1.pdf. Accessed 3 December 2021.

Welsh Government Technical Advisory Group Children and Education, c., Evidence review on Children and Young People Under 18 in Preschool, School or College following the Firebreak - o9/11/ Available at: https:/gov.wales/sites/default/files/ publications/202O-11/technical-advisory-group-evidence-review-on-children-andyoung-people-under-18-in-preschool-school-or-college-following-the-firebreak. pdf. Accessed 30 November 2020.

Welsh Government, "Deputy Minister Health and Social Services Letter to Chair of Welsh Parliament Children and Young People and Education Committee, 23rd September 2020". Available at: https://business.senedd.wales/documents/s105741/Welsh\%2O Government\%2oresponse\%2O-\%2O23\%2oSept. Accessed 17 February 2021.

Wightwick, A., "Teaching Union tells Mark Drakeford schools should not open on Monday because 'it's not safe' and 'teachers could die."' Wales Online, 19 February 2021. Williams, J., "Multi-level governance and crc implementation", in , A. Invernizzi and J. Williams (eds.), The Human Rights of Children: From Visions to Implementation (Farnham: Ashgate, 2011).

Williams, J. (ed.), The UNCRC in Wales (Cardiff: University of Wales Press, 2013). 